\title{
Hypercalcaemia and hypocalcaemia: finding the balance
}

\author{
Jean-Jacques Body ${ }^{1} \cdot$ Daniela Niepel $^{2} \cdot$ Giuseppe Tonini $^{3}$
}

Received: 19 August 2016 / Accepted: 12 December 2016/Published online: 12 January 2017

(C) The Author(s) 2017. This article is published with open access at Springerlink.com

\begin{abstract}
Calcium metabolism in cancer and hypercalcaemia of malignancy The balance between bone formation and resorption may be disrupted in patients with cancer, leading either to increased bone resorption, calcium release, and possibly hypercalcaemia, or to increased bone formation, sequestration of calcium, and possibly hypocalcaemia. In adults, hypercalcaemia of malignancy is most common in patients with tumours that produce factors that induce osteoclast activation and enhance bone resorption. Impaired renal function and increased renal tubular calcium resorption may further affect calcium levels.
\end{abstract}

Highlights

- Disruption of bone turnover in cancer can lead to hypercalcaemia or hypocalcaemia

- Both conditions can be serious if left untreated

- Agents that inhibit bone resorption are effective treatments for hypercalcaemia

- Bone resorption inhibitors can cause or aggravate hypocalcaemia

- Physicians need to monitor calcium levels when treating patients with cancer

Jean-Jacques Body

Jean-jacques.BODY@ chu-brugmann.be

Daniela Niepel

dniepel@amgen.com

Giuseppe Tonini

g.tonini@unicampus.it

1 Department of Medicine (K1), CHU Brugmann (Université Libre de Bruxelles), Place Van Gehuchten, 1020 Brussels, Belgium

2 Amgen (Europe) GmbH, Vienna, Austria

3 Department of Oncology, Policlinico Universitario Campus Bio-Medico, Rome, Italy
Treatment of hypercalcaemia of malignancy Inhibitors of bone resorption, first the bisphosphonates and, later, denosumab, have been shown to be effective in hypercalcaemia treatment. Bisphosphonates (which are administered intravenously) are approved for hypercalcaemia of malignancy and are the current mainstay of treatment, whereas denosumab (which is administered subcutaneously) may offer an option for patients who do not respond to bisphosphonates or suffer from renal insufficiency.

Hypocalcaemia: treatment and prevention Hypocalcaemia is most common in patients with prostate cancer and osteoblastic bone metastases, but can occur in patients with a variety of tumour types who are receiving inhibitors of bone resorption. While patients often respond to calcium and vitamin D supplementation, prevention should be the aim; at-risk patients should be identified before starting treatment with inhibitors of bone resorption, be closely monitored during at least the first few months of treatment, and receive concomitant calcium and vitamin D supplementation unless hypercalcaemia is present.

Conclusion Both hypercalcaemia and hypocalcaemia can be serious if left untreated. It is therefore important that patients with cancer are closely monitored and receive adequate prevention and treatment measures to maintain normal blood calcium levels.

Keywords Hypercalcaemia $\cdot$ Hypocalcaemia . Hypercalcaemia of malignancy · Denosumab .

Bisphosphonates

\section{Introduction}

Several organs contribute to the maintenance of healthy blood calcium levels, including the kidneys, parathyroid glands, 
intestines, and bone. The bone is a dynamic tissue that is constantly being remodelled by specialised bone-forming cells, osteoblasts, and bone-resorbing cells, osteoclasts [1], and acts as a major calcium sink [1,2]. The normal balance of bone metabolism is often uncoupled in patients with advanced cancer, particularly in those with metastatic bone lesions. This can lead to hypercalcaemia of malignancy or hypocalcaemia, both of which can have serious consequences.

In order to maintain blood calcium homeostasis in patients with cancer, it is important to understand the underlying mechanisms of hypercalcaemia and hypocalcaemia in the context of the management of metastatic bone disease.

\section{Calcium metabolism in cancer}

The balance of bone formation and resorption can be disrupted in patients with cancer by systemic factors released from the primary tumour and by local effectors released from tumour cells that have metastasised to bone (Fig. 1) [1].

In osteoblastic metastases, tumour cells produce osteoblaststimulating factors, such as endothelin-1, platelet-derived growth factor, fibroblast growth factor, and bone morphogenetic proteins, proteases (e.g. matrix metalloproteinases, prostate-specific antigen, urokinase-type plasminogen activator), all of which promote osteoblast proliferation and bone formation (Fig. 1) [4-7]. Osteoblastic metastases are common in patients with prostate cancer [8,9]; endothelin- 1 has been shown to be increased in the blood of such patients [6]. Calcium is sequestered from the blood during the development of osteoblastic metastases [10]; therefore, patients with prostate cancer and osteoblastic metastases are most at risk of developing hypocalcaemia.

In osteolytic metastases, tumour cells release factors that ultimately activate osteoclasts (Fig. 1). In breast cancer, the most important of these factors is parathyroid hormone-related protein (PTHrP) [11-13]. Other examples include transforming growth factor beta [14], interleukin-1 and interleukin-6, and tumour necrosis factor alpha [15]. These factors stimulate bone marrow stromal and osteoblast cells to express RANK ligand (RANKL), which signals via its cognate receptor RANK, expressed on osteoclast precursor cells and activated osteoclasts [16]. Signalling through the RANK receptor induces osteoclast maturation and bone resorption [17-19]. During bone resorption, calcium is released causing a rise in blood calcium concentration [2]. Additionally, growth factors stored in the bone matrix are released and stimulate tumour cell proliferation and further release of PTHrP, feeding into the vicious cycle of bone metastases and tumour growth [20]. Tumours of the breast and lung, and multiple myeloma, predominantly cause osteolytic metastases and lytic bone lesions, respectively [21-23]; patients with these malignancies are, therefore, most at risk of developing hypercalcaemia of malignancy.

Although there are clear distinctions in the causes and epidemiology of osteolytic and osteoblastic bone metastases, it should be noted that these two types of bone lesion represent extremes of a spectrum of metastatic bone disease [24]; a substantial proportion of patients have bone metastases with both osteolytic and osteoblastic elements. For example, in one study, the majority of patients with castration-resistant prostate cancer, a spectrum of bone lesions from osteolytic to osteoblastic was present [25].

Calcium homeostasis can also be disrupted in patients with advanced cancer that has not metastasised to bone. In these patients, tumour-derived systemic factors (predominantly PTHrP) increase blood calcium concentrations by enhancing osteoclast activation and bone resorption and by increasing renal tubular calcium reabsorption [26].

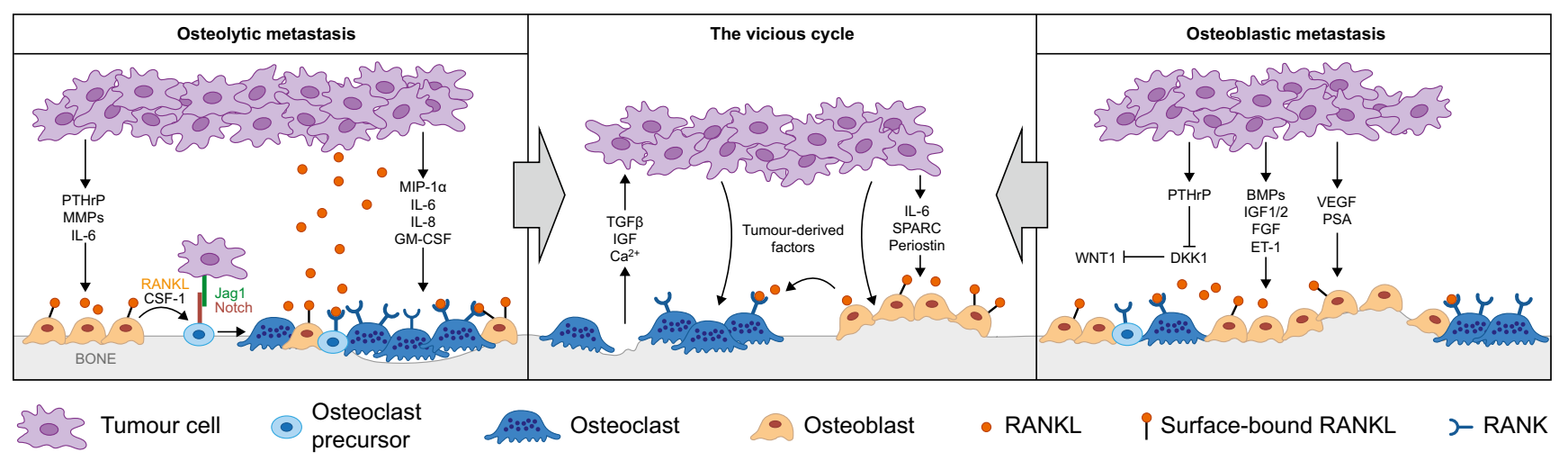

Fig. 1 Mechanisms underlying osteolytic and osteoblastic metastasis. Adapted from Cell, Vol: 151, Ell B. and Kang Y. Snapshot: bone metastasis, Pages: 690-90. Copyright (2015), with permission from Elsevier [3]. BMP bone morphogenetic protein, $C S F-1$ colonystimulating factor $1, D K K 1$ Dickkopf Wnt signalling pathway inhibitor 1, ET-1 endothelin 1, FGF fibroblast growth factor, $G M$ $C S F$ granulocyte-macrophage colony-stimulating factor, $I G F$ insulinlike growth factor, $I G F \quad 1 / 2$ insulin-like growth factor $1 / 2, I L-6$ interleukin $6, I L-8$ interleukin $8, M I P-1 a$ macrophage inflammatory protein 1 alpha, MMP matrix metalloproteinase, $P S A$ prostatespecific antigen, $P T H r P$ parathyroid hormone-related protein, $R A N K$ receptor activator of nuclear factor kappa $\mathrm{B}, R A N K L$ receptor activator of nuclear factor kappa B ligand, SPARC secreted protein acidic and cysteine rich, $T G F$ transforming growth factor beta, $V E G F$ vascular endothelial growth factor, Wntl wingless-type MMTV integration site family member 1 
A summary of the key factors contributing to the development of hypercalcaemia and hypocalcaemia, by primary tumour, is presented in Table 1.

\section{Hypercalcaemia of malignancy}

Previous estimates of hypercalcaemia of malignancy reported that it occurred in 5-30\% of patients with cancer [30]. However, prevalence rates have fallen progressively with the widespread, early and prolonged use of agents that inhibit bone resorption [31, 32]. A recent observational study in patients with cancer of any type or stage found that the 2012 hypercalcaemia prevalence was $0.67 \%$; prevalence estimates varied across cancer types and were highest for individuals with lung cancer, multiple myeloma, or stage IV cancer [33]. Similarly, a recent US study reported a hypercalcaemia prevalence of $2-2.8 \%$ among all patients with cancer, ranging from $1.4-2.1 \%$ in prostate cancer, to $7.5-10.2 \%$ in multiple myeloma [34]. Furthermore, both studies examined the prevalence of hypercalcaemia in patients with cancer and not specifically hypercalcaemia of malignancy; therefore, the prevalence of true hypercalcaemia of malignancy is likely to be lower. Indeed, a study of 642 patients diagnosed with hypercalcaemia of malignancy reported that up to one third of cases were not caused by tumour-related factors [35].

Signs and symptoms of hypercalcaemia include polyuria, nausea and vomiting, constipation, weakness, obtundation, and, in severe cases, coma [30,36]. Early symptoms can be mild and difficult to distinguish from the underlying cancer or side effects of cancer therapy. When hypercalcaemia of malignancy is suspected, blood calcium concentrations should be measured; total blood calcium concentrations, adjusted for albumin, above $10.2 \mathrm{mg} / \mathrm{dL}$ are diagnostic of hypercalcaemia [1]. It should be noted, however, that disease development and the severity of symptoms are related to both the absolute blood calcium level and to the rate of increase $[1,30,36]$.

Hypercalcaemia of malignancy can occur in patients with or without osteolytic bone metastases and is thus classified as

Table 1 Summary of incidence of and mechanisms underlying calcium imbalance, by malignancy [1,27-29]

\begin{tabular}{|c|c|c|}
\hline Malignancy & Hypercalcaemia & Hypocalcaemia \\
\hline Prostate & $\begin{array}{l}\text { - Prostate cancer accounts for only } \sim 3 \% \text { of cases of hypercalcaemia of } \\
\text { malignancy. Therefore, hypercalcaemia is very rare in this patient } \\
\text { population } \\
\text { - Strong association with bone metastases, although these are not } \\
\text { typically osteolytic }\end{array}$ & $\begin{array}{l}\text { - High risk of hypocalcaemia. Low calcium levels have been } \\
\text { reported to occur in up to } 30 \% \text { of patients with advanced } \\
\text { prostate cancer } \\
\text { - Strong association with bone metastases, which are most } \\
\text { commonly osteoblastic } \\
\text { - Grade } \geq 2 \text { hypocalcaemia might be expected in } 6-21 \% \text { of } \\
\text { patients treated with inhibitors of bone resorption } \\
\text { - Prostate cancer is a risk factor for development of grade } \geq 2 \\
\text { hypocalcaemia during treatment with inhibitors of bone } \\
\text { resorption }\end{array}$ \\
\hline Breast & $\begin{array}{l}\text { - Breast cancer accounts for } \sim 25 \% \text { of cases of hypercalcaemia of } \\
\text { malignancy } \\
\text { - Strong association with bone metastases, which are typically } \\
\text { osteolytic } \\
\text { - PTHrP is an important mediator of hypercalcaemia in both } \\
\text { metastatic and non-metastatic breast cancer }\end{array}$ & $\begin{array}{l}\text { - Hypocalcaemia might be expected in } 6-8 \% \text { of patients treated } \\
\text { with inhibitors of bone resorption }\end{array}$ \\
\hline Lung & $\begin{array}{l}\text { - Lung cancer accounts for } \sim 35 \% \text { of cases of hypercalcaemia of } \\
\text { malignancy } \\
\text { - Can be associated with bone metastases, which may be osteolytic } \\
\text { - PTHrP may be an important mediator of paraneoplastic } \\
\text { hypercalcaemia } \\
\text { - Rare reports of ectopic tumour-produced PTH associated with } \\
\text { hypercalcaemia }\end{array}$ & $\begin{array}{l}\text { - Hypocalcaemia might be expected in } 3-18 \% \text { of patients with } \\
\text { lung cancer treated with inhibitors of bone resorption } \\
\text { - SCLC is a risk factor for development of grade } \geq 2 \\
\text { hypocalcaemia during treatment with inhibitors of bone } \\
\text { resorption }\end{array}$ \\
\hline Haematological & $\begin{array}{l}\text { - Haematological cancers account for } \sim 14 \% \text { of cases of } \\
\text { hypercalcaemia of malignancy } \\
\text { - Bone metastases are typically osteolytic, associated with risk of } \\
\text { hypercalcaemia } \\
\text { - PTHrP and } 1,25-(\mathrm{OH})_{2} \mathrm{D}_{3} \text { may be important mediators of } \\
\text { hypercalcaemia }\end{array}$ & $\begin{array}{l}\text { - Hypocalcaemia might be expected in } 8-13 \% \text { of patients with } \\
\text { multiple myeloma treated with inhibitors of bone resorption }\end{array}$ \\
\hline Renal & $\begin{array}{l}\text { - Renal cancer accounts for } \sim 3 \% \text { of cases of hypercalcaemia of } \\
\text { malignancy } \\
\text { - Bone metastases, which may be osteolytic, associated with risk of } \\
\text { hypercalcaemia } \\
\text { - PTHrP may be a mediator of hypercalcaemia }\end{array}$ & - Risk of hypocalcaemia with inhibitors of bone resorption \\
\hline
\end{tabular}

PTHrP parathyroid hormone-related protein, SCLC small-cell lung cancer 
osteolytic or humoral, respectively [32, 37]. Elevation of circulating PTHrP level has a central role in the pathogenesis of both humoral and osteolytic hypercalcaemia of malignancy [26]. A study of 30 patients with solid tumours and humoral hypercalcaemia of malignancy revealed that up to $80 \%$ of individuals had raised plasma PTHrP concentrations compared with healthy controls [38]. Elevated circulating PTHrP levels have also been reported in $65 \%$ of patients with bone metastases and hypercalcaemia [39].

Although hypercalcaemia of malignancy often occurs with metastatic bone disease, there is no clear correlation between the extent of bone metastases and the development or severity of hypercalcaemia [40]. This is probably because osteolytic and humoral factors can be present together; a study of 443 patients with cancer and hypercalcaemia showed that $53 \%$ of patients had osteolytic hypercalcaemia, 35\% had humoral hypercalcaemia, and $12 \%$ had both osteolytic and humoral factors [35]. Furthermore, renal function and the extent of renal tubular calcium resorption also affect blood calcium levels [30].

Hypercalcaemia is associated with poor prognosis. Median survival has been shown to be only 52 and 54 days for patients with mixed solid tumours [41] or colorectal cancer [42], respectively, increasing to 3.5 months in lung cancer [43] and 4.5 months in breast cancer [44]. Furthermore, there are data suggesting that the underlying pathology of hypercalcaemia of malignancy adversely influences prognosis; a prospective case series of 76 individuals with hypercalcaemia of malignancy showed that, for those aged 65 years or older, mortality was higher in patients with higher pretreatment blood calcium and elevated PTHrP levels than in those with lower calcium and normal PTHrP levels [45].

Benign causes of hypercalcaemia should also be considered when diagnosing patients with cancer. To confirm a diagnosis of hypercalcaemia, blood calcium (adjusted for albumin) and PTH concentration should be measured. If PTH levels are not supressed then primary hyperparathyroidism must be suspected. Vitamin D $(25(\mathrm{OH})$ vitamin $\mathrm{D})$ should also be measured to eliminate excess vitamin $\mathrm{D}$ as the cause of hypercalcaemia [46]. Hyperparathyroidism has been shown to be a predominant non-malignant cause of hypercalcaemia and so requires a different treatment strategy. Other causes of hypercalcaemia are much less frequent than hyperparathyroidism [35]. Therefore, in order to optimise the care of patients with cancer and hypercalcaemia, it is important to exclude other causes, which are mainly primary hyperparathyroidism and, more rarely, excess vitamin D.

\section{Treatment of hypercalcaemia of malignancy}

The most effective therapy for patients with hypercalcaemia of malignancy is treatment of the underlying cancer in order to reduce tumour production of factors that promote bone resorption and renal tubular calcium reabsorption; however, this may not be possible or effective in patients with advanced cancer [36]. Therapies that inhibit bone resorption and promote renal calcium excretion therefore become important. Most patients with hypercalcaemia of malignancy are dehydrated at presentation and rehydration is often the first step of treatment. Saline should be given at a maximal initial rate of $200-300 \mathrm{~mL} / \mathrm{h}$, then adjusted to maintain a urine output of $100-150 \mathrm{~mL} / \mathrm{h} \mathrm{[46]}$. This, however, relieves the symptoms rather than addressing the underlying disease, and therefore, rehydration alone rarely resolves hypercalcaemia [47]. Nearly all patients with hypercalcaemia of malignancy have increased osteoclastic bone resorption; hence, inhibition of bone resorption is a key target for management of the condition [1].

Bisphosphonates, the first class of agents that inhibit bone resorption, are synthetic analogues of pyrophosphonate (a natural regulator of bone metabolism) and are preferentially localised to the extracellular bone matrix. From there, bisphosphonates may inhibit the differentiation of osteoclastic precursors, induce apoptosis of osteoclasts and stimulate the release of osteoclastic inhibitory factors from osteoblasts [48]. The bisphosphonates commonly used to correct hypercalcaemia are clodronate, pamidronate, ibandronate and zoledronic acid [49]. Zoledronic acid (a nitrogencontaining bisphosphonate), at a dose of $4 \mathrm{mg}$ infused over $15 \mathrm{~min}$, is approved in the USA and the European Union for the treatment of hypercalcaemia of malignancy and the prevention of skeletal-related events (SREs) in patients with bone metastases [50, 51]. At this approved dose, zoledronic acid will lead to a reduction in blood calcium concentration within 2-3 days of administration [46]. Zoledronic acid was shown to have greater efficacy than pamidronate in the treatment of hypercalcaemia of malignancy in a pooled analysis of two randomised, double-blind, phase 3 trials involving 275 patients with moderate-to-severe hypercalcaemia of malignancy. Treatment with zoledronic acid resulted in a significantly higher proportion of complete responses by day 10 (88.4 versus $69.7 \% ; P=0.002$ ) (Fig. 2a), more rapid calcium normalisation, and more durable responses than treatment with pamidronate [52]. Renal adverse events were more frequent, however, in the patients receiving zoledronic acid; it is, therefore, not recommended if creatinine clearance is less than $30 \mathrm{~mL} / \mathrm{min}$ [50]. Ibandronate, also a nitrogen-containing bisphosphonate, has been successfully used, notably in patients with myeloma and renal failure [54]. Although not currently indicated for the treatment of hypercalcaemia of malignancy, ibandronate may offer an alternative therapy for patients with renal failure [55].

More than $90 \%$ of patients with hypercalcaemia of malignancy can be successfully treated with rehydration and bisphosphonates; however, some patients do not respond to or experience relapse on bisphosphonate therapy. Persistent or relapsed hypercalcaemia of malignancy remains a difficult 
A
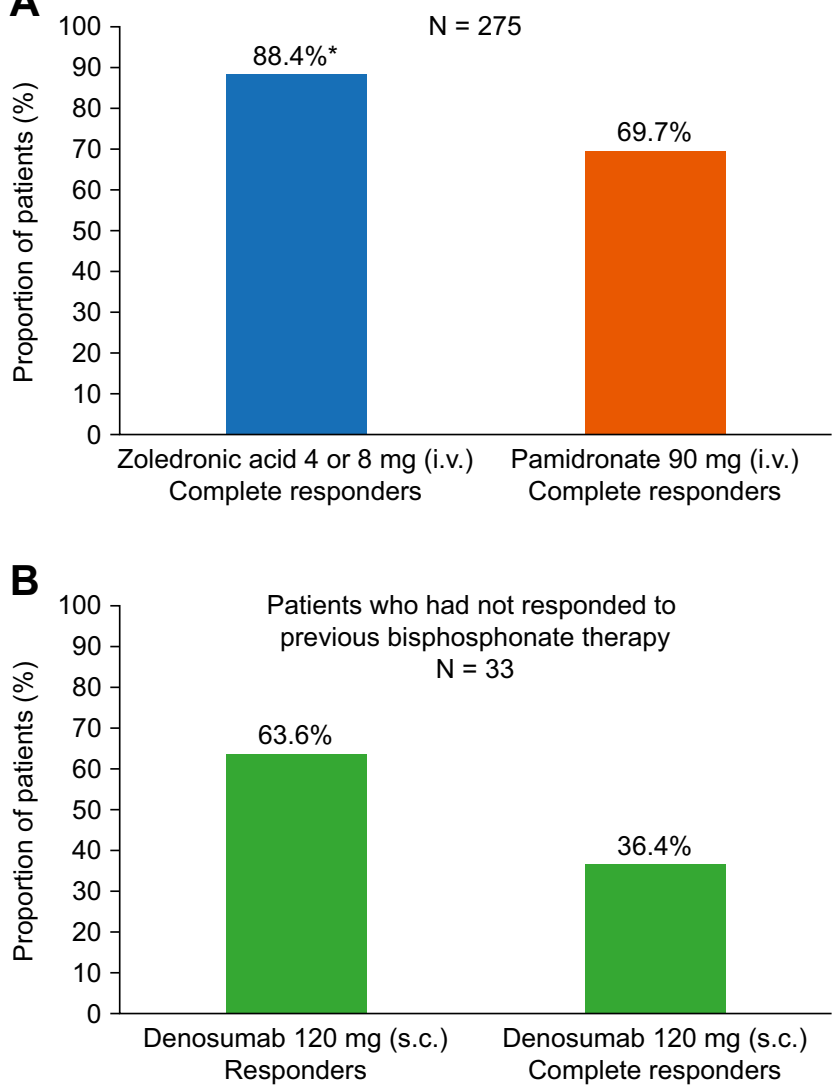

Fig. 2 Responses to treatment with bisphosphonates or denosumab. a Proportion of patients demonstrating a complete response at day 10 in a pooled analysis of two randomised, double-blind phase 3 trials of patients with moderate-to-severe hypercalcaemia of malignancy who received zoledronic acid or pamidronate $(N=275)$. Complete response was defined as CSC $\leq 10.8 \mathrm{mg} / \mathrm{dL}(2.7 \mathrm{mmol} / \mathrm{L})$. [52]. b Proportion of patients demonstrating a response or complete response at day 10 in a single-arm, open-label study of patients who had hypercalcaemia of malignancy (CSC levels $>12.5 \mathrm{mg} / \mathrm{dL}[3.125 \mathrm{mmol} / \mathrm{L}]$ ) despite receiving bisphosphonate treatment. During the study, patients $(N=33)$ received denosumab $120 \mathrm{mg}$ s.c. and response was defined as $\mathrm{CSC}<11.5 \mathrm{mg} / \mathrm{dL}(2.9 \mathrm{mmol} / \mathrm{L} ;$ CTCAE grade 0 or 1$)$. Complete response was defined as CSC $\leq 10.8 \mathrm{mg} / \mathrm{dL}(2.7 \mathrm{mmol} / \mathrm{L})$. [53]. $* P=0.002$ versus pamidronate. CSC albumin-corrected serum calcium, CTCAE Common Terminology Criteria for Adverse Events, i.v. intravenous, s.c. subcutaneous

complication to manage [56]. Denosumab, a fully-human IgG2 monoclonal antibody against RANKL that disrupts signalling through RANK and prevents tumour-mediated activation of osteoclasts [57], has been shown to be effective for the treatment of patients with bisphosphonate-refractory hypercalcaemia. In a single-arm, open-label study, 33 patients with hypercalcaemia of malignancy despite recent bisphosphonate treatment received denosumab $120 \mathrm{mg}$ on days 1,8 , 15 , and 29 , and then every 4 weeks. In total, $64 \%$ of patients responded to denosumab treatment by day 10 , with $36 \%$ of patients experiencing a complete response (Fig. 2b) [53]. The results of this study formed the basis of the approval of denosumab for the treatment of bisphosphonate-refractory hypercalcaemia of malignancy in the USA, Australia, Canada, and Russia [58-61]. Denosumab, therefore, offers a new treatment option for patients with persistent hypercalcaemia that does not respond to bisphosphonates or hypercalcaemia that relapses following bisphosphonate treatment.

Inhibitors of bone resorption are used to prevent SREs, which are associated with substantial pain and morbidity [62], in patients with metastatic bone disease [50, 63]. The risk of SREs is high in these patients, with up to $64 \%$ of those with advanced breast, prostate or lung cancer experiencing an SRE [64-67]. Furthermore, many patients experience multiple SREs over the course of their disease; individuals with breast cancer can experience a mean of 3.7 SREs per year, if left untreated [64]. Adequate preventive treatment is, therefore, a priority. Denosumab has shown superiority over zoledronic acid in preventing SREs in patients with bone metastases [68]. There is also preliminary evidence suggesting that denosumab may offer advantages over zoledronic acid in terms of delaying the onset of and reducing the occurrence or risk of hypercalcaemia of malignancy. A post hoc analysis of data from two phase 3, randomised, controlled trials comparing denosumab and zoledronic acid for the prevention of SREs in patients with bone metastases demonstrated that denosumab significantly delayed the time to first on-study hypercalcaemia event by $37 \%$ (hazard ratio, $0.63 ; 95 \%$ confidence interval (CI), 0.41-0.98; $P=0.042$ ). Furthermore, fewer patients receiving denosumab experienced such an event (1.7\% compared with $2.7 \%$ of those receiving zoledronic acid; $P=0.028$ ), and treatment with denosumab reduced the risk of developing recurrent hypercalcaemia of malignancy by $52 \%$ compared with zoledronic acid (rate ratio, $0.48 ; 95 \% \mathrm{CI}$, $0.29-0.81 ; P=0.006$ ) [69-71]. These data must be interpreted cautiously, however, as neither study was powered to look for statistically significant differences in the occurrence of hypercalcaemia between the study arms. Despite this, denosumab may be considered to be a more potent inhibitor of bone resorption than zoledronic acid and may offer a superior option to prevent hypercalcaemia of malignancy. Denosumab also offers further advantages in that it is administered subcutaneously rather than intravenously, and it may be useful in patients with renal insufficiency.

In patients with severe hypercalcaemia, the hormone calcitonin is an important adjunctive treatment that acts within $4 \mathrm{~h}$ of administration and can be used to immediately reduce calcium plasma concentrations. Calcitonin reduces calcium concentration by inhibiting osteoclast activity and increasing renal calcium clearance. It should be given at a dose of 4-8 units $/ \mathrm{kg}$ subcutaneously or intramuscularly every 6-12 h; duration of dosing is, however, limited to $48 \mathrm{~h}$ owing to the development of tachyphylaxis and decreased responsiveness [46].

Currently, the standard treatment for hypercalcaemia of malignancy is rehydration combined with intravenous 
bisphosphonate therapy, with zoledronic acid preferred over pamidronate $[36,52]$. In some countries, denosumab is approved for use in patients with bisphosphonate-refractory hypercalcaemia [53]. In addition, calcitonin may be useful for patients with severe or life-threatening hypercalcaemia because it causes a rapid, albeit transient, decrease of high serum calcium levels $[46,72]$.

\section{Hypocalcaemia}

Hypocalcaemia can cause muscle spasms, irritability, tetany, paraesthesias, seizures, and cardiac dysrhythmias. Its incidence is difficult to estimate because the aetiology is multifactorial. Defined as corrected total blood calcium below $8.5 \mathrm{mg} /$ $\mathrm{dL}$ or ionised blood calcium below $4.6 \mathrm{mg} / \mathrm{dL}$, hypocalcaemia occurs in approximately $30 \%$ of all patients with advanced prostate cancer $[27,28]$. In patients with osteoblastic bone metastases, excessive uptake of calcium by bone-forming metastases, which sequester calcium, is a primary cause of hypocalcaemia [73]. Renal insufficiency can also contribute to the development of low blood calcium levels $[74,75]$.

The use of inhibitors of bone resorption for the prevention of SREs in patients with metastatic bone disease may induce or worsen hypocalcaemia, both in patients with prostate cancer [76-78] and patients with other tumours that metastasise to bone $[29,79,80]$; individuals with prostate cancer and osteoblastic metastases are most at risk of developing hypocalcaemia as an adverse effect of such treatment. Other risk factors include high baseline levels of bone turnover markers (urinary N-telopeptide of type I collagen and bonespecific alkaline phosphatase) and reduced creatinine clearance (Table 2) [29]. Bisphosphonates and denosumab prevent bone resorption by inhibiting osteoclast activity and thus diminish calcium mobilisation as a consequence of bone turnover. Treatment with inhibitors of bone resorption may also cause a shift of calcium into the bone if large populations of osteoblasts exist, as in osteoblastic metastases [81, 82], or when there is excess osteoid tissue (e.g. as a consequence of long-term vitamin D deficiency) [29]. Hypocalcaemia occurs more frequently in patients receiving denosumab than in those receiving zoledronic acid (Fig. 3); a combined analysis of three phase 3 trials comparing denosumab and zoledronic acid reported hypocalcaemia of grade 3 or higher in $3.1 \%$ and $1.3 \%$ of patients in the denosumab and zoledronic acid groups, respectively [83]. By contrast, an open-label extension of two of these trials, in which 295 patients received monthly denosumab for more than 3 years, reported similar rates of hypocalcaemia: $4.6 \%$ of patients who had received denosumab and $3.1 \%$ of patients who switched from zoledronic acid to denosumab experienced hypocalcaemia [84]. Thus, hypocalcaemia associated with denosumab appears to occur most often during the initial stages of therapy, but 'stabilises' thereafter and does not seem to increase with increased duration of exposure [29]. The increased risk of hypocalcaemia seen with denosumab is consistent with it being a more potent inhibitor of bone resorption than zoledronic acid [29]. Hypocalcaemia associated with treatment with inhibitors of bone resorption is often mild and transient, but can be severe, with some patients requiring hospitalisation and clinical intervention [79]. Hypocalcaemia must, therefore, be prevented wherever possible and managed in the context of the current management of metastatic bone disease.

\section{Treatment and prevention of hypocalcaemia}

Hypocalcaemia in patients with cancer can have severe consequences, whether occurring with or without the use of inhibitors of bone resorption, but responds well to calcium and
Table 2 Factors significantly associated with the risk of developing grade $\geq 2$ hypocalcaemia among denosumab-treated patients participating in three identically designed phase 3 trials of denosumab $120 \mathrm{mg}$ s.c. $(N=2841)$ versus zoledronic acid 4 mg i.v. $(N=2836)$. Adapted with permission from Body $\mathrm{JJ}$ et al. Eur J Cancer 2015 [29]

\begin{tabular}{|c|c|c|c|}
\hline \multirow[t]{2}{*}{ Demographic variable/baseline disease characteristic } & \multicolumn{3}{|c|}{ Denosumab } \\
\hline & $\begin{array}{l}\text { Point } \\
\text { estimate }\end{array}$ & $95 \% \mathrm{CI}$ & $P$ value \\
\hline Sex (male versus female) & 0.761 & $0.459-1.262$ & NS \\
\hline Tumour type - prostate cancer & 2.193 & $1.210-3.974$ & 0.0096 \\
\hline Tumour type - SCLC & 4.982 & $2.252-11.021$ & $<0.0001$ \\
\hline $\begin{array}{l}\text { Baseline creatinine clearance ( } 30 \text { to }<60 \mathrm{~mL} / \text { min versus } \\
\geq 60 \mathrm{~mL} / \mathrm{min} \text { ) }\end{array}$ & 1.414 & $1.039-1.924$ & 0.0276 \\
\hline $\begin{array}{l}\text { Baseline corrected uNTx level (> } 50 \mathrm{nmol} / \mathrm{mmol} \text { versus } \\
\leq 50 \mathrm{nmol} / \mathrm{mmol} \text { ) }\end{array}$ & 1.305 & $1.018-1.673$ & 0.0360 \\
\hline Baseline BSAP level ( $>$ median versus $\leq$ median; $20.77 \mu \mathrm{g} / \mathrm{L}$ ) & 1.734 & $1.280-2.348$ & 0.0004 \\
\hline Number of bone metastases $(>2$ versus $\leq 2)$ & 0.631 & $0.312-1.275$ & NS \\
\hline $\begin{array}{l}\text { Interaction between baseline BSAP and number of bone } \\
\text { metastases }\end{array}$ & 2.419 & $1.154-5.071$ & 0.0193 \\
\hline Type of lesion - osteoblastic & 1.197 & $0.870-1.647$ & NS \\
\hline
\end{tabular}

$B S A P$ bone-specific alkaline phosphatase, $C I$ confidence interval, i.v. intravenous, $N S$ not significant, $s . c$. subcutaneous, $S C L C$ small-cell lung cancer, $u N T x$ urinary N-telopeptide of type I collagen 


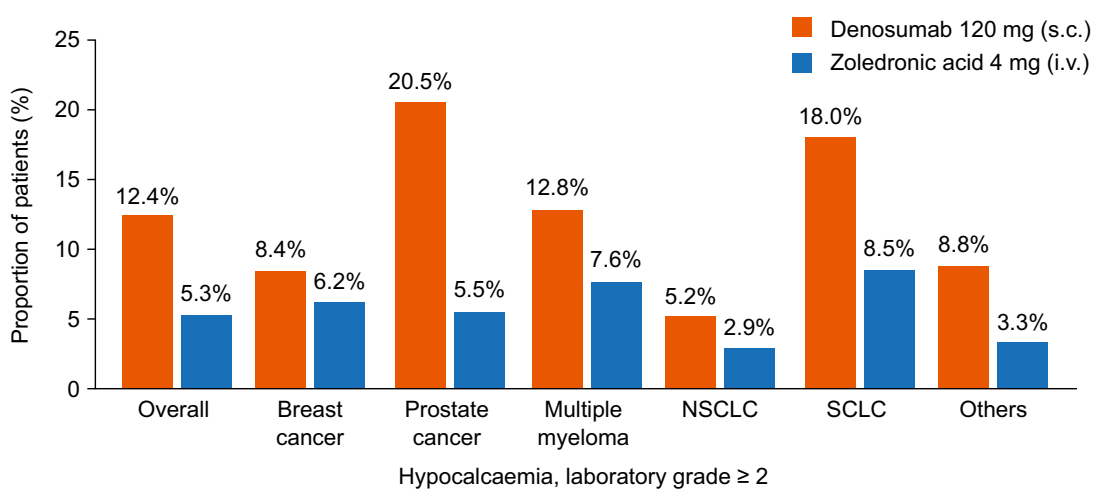

Fig. 3 Incidence of laboratory grade $\geq 2$ hypocalcaemia by tumour type. Reproduced with permission from European Journal of Cancer, Vol: 51, Body JJ et al. Pages: 1812-1821 (http://dx.doi.org/10.1016/j.

vitamin D supplementation [74, 80, 85, 86]. Furthermore, when treatment with inhibitors of bone resorption is required for the management of metastatic bone disease, hypocalcaemia can usually be prevented by identification and appropriate management of at-risk patients [29]. Case reports and retrospective analyses have identified a number of risk factors associated with the development of hypocalcaemia in those receiving inhibitors of bone resorption; these include vitamin D deficiency, renal insufficiency, osteoblastic metastases, prostate cancer, and low baseline blood calcium levels (Table 2) [29, 78-80]. It is therefore important that vitamin D and calcium levels are assessed and supplementation initiated before starting treatment with inhibitors of bone resorption. This evaluation is particularly important given the high prevalence of vitamin D insufficiency or deficiency among patients with metastatic cancer [87]. Furthermore, all patients receiving inhibitors of bone resorption for the prevention of SREs should receive concomitant calcium and vitamin D supplementation; use of these supplements has been shown to lower the risk of developing hypocalcaemia by $27 \%$ and $40 \%$ in patients receiving zoledronic acid or denosumab, respectively [29]. An interim analysis of an open-label observational study of treatment persistence in patients with cancer who were receiving denosumab to prevent SREs found that most patients $(80 \%)$ received calcium and vitamin D supplementation at the start of denosumab treatment. Long-term follow-up persistence data, however, are not yet available [88]. Previous reports suggest that adherence to calcium and vitamin D supplementation is low [89]; patients should, therefore, be counselled on the importance of adequate calcium and vitamin $\mathrm{D}$ intake in order to improve adherence [90]. Use of 1,25-dihydroxyvitamin D, the active metabolite of vitamin $\mathrm{D}$, might offer further advantages in the prevention and treatment of hypocalcaemia; however, trials are required to confirm this.

Although hypocalcaemia can occur at any time during treatment with inhibitors of bone resorption, studies show that it often develops soon after treatment initiation; within 7 days, ejca.2015.05.016) Copyright (2015), with permission from Elsevier (https://creativecommons.org/licenses/by-nc-nd/2.0/) [29]. NSCLC nonsmall-cell lung cancer, $S C L C$ small-cell lung cancer

in some cases [79, 91]. Therefore, careful monitoring of atrisk patients after starting treatment is important to enable quick detection and resolution of hypocalcaemia [79, 91]. At-risk patients should also be educated about the symptoms of hypocalcaemia and encouraged to report any indicative symptoms [29]. If hypocalcaemia occurs while a patient is receiving inhibitors of bone resorption, additional calcium and vitamin D supplementation and further monitoring are advised. Delaying the administration of inhibitors of bone resorption because of hypocalcaemia is rarely necessary.

\section{Conclusion}

Both hypercalcaemia and hypocalcaemia can lead to serious complications in patients with advanced cancer. Bisphosphonates are effective treatments for both osteolytic and humoral hypercalcaemia of malignancy. In patients with persistent or relapsed hypercalcaemia of malignancy that fails to respond or no longer responds to bisphosphonate treatment, denosumab offers a therapeutic option and, as such, has been approved for this indication in the USA, Australia, Canada, and Russia. Denosumab is a more potent inhibitor of bone resorption than zoledronic acid and is more effective at preventing hypercalcaemia. It is possible that the incidence of hypercalcaemia of malignancy may further decrease as potent inhibitors of bone resorption are used more commonly and earlier in the course of management of patients with metastatic cancer. On the other hand, inhibitors of bone resorption have been shown to increase the risk of developing hypocalcaemia. This risk is higher with denosumab than with zoledronic acid; however, it can be managed by proper identification of at-risk patients and careful monitoring of those receiving these agents. Given the potential improvements to quality of life that inhibitors of bone resorption offer patients with advanced cancer, the benefits and risks associated with their use must be assessed. Further to this, physicians need to be aware of the measures they can take to counteract these 
risks and to find the balance between hypercalcaemia and hypocalcaemia.

Acknowledgements Medical writing support, funded by Amgen (Europe) $\mathrm{GmbH}$, was provided by Kelly Soady $\mathrm{PhD}$ from Oxford PharmaGenesis and Emma Booth from Amgen (Europe) GmbH. Editorial support was provided by Sarah Petrig of Amgen (Europe) $\mathrm{GmbH}$.

\section{Compliance with ethical standards}

Conflicts of interest J-JB has served as a consultant for and received lecture fees from Amgen. DN is an employee and shareholder of Amgen. GT has served on advisory board for Celgene, Novartis and Roche.

Open Access This article is distributed under the terms of the Creative Commons Attribution-NonCommercial 4.0 International License (http:// creativecommons.org/licenses/by-nc/4.0/), which permits any noncommercial use, distribution, and reproduction in any medium, provided you give appropriate credit to the original author(s) and the source, provide a link to the Creative Commons license, and indicate if changes were made.

\section{References}

1. Clines GA, Guise TA (2005) Hypercalcaemia of malignancy and basic research on mechanisms responsible for osteolytic and osteoblastic metastasis to bone. Endocrine-related cancer 12(3):549583. doi: $10.1677 /$ erc. 1.00543

2. Roodman GD (2004) Mechanisms of bone metastasis. New Eng J Med 350(16):1655-1664. doi:10.1056/NEJMra030831

3. Ell B, Kang Y (2012) SnapShot: bone metastasis. Cell 151 (3):690690.e1. doi:10.1016/j.cell.2012.10.005

4. Body JJ, Casimiro S, Costa L (2015) Targeting bone metastases in prostate cancer: improving clinical outcome. Nat Rev Urol 12(6): 340-356. doi:10.1038/nrurol.2015.90

5. Canalis E, Centrella M, McCarthy T (1988) Effects of basic fibroblast growth factor on bone formation in vitro. J Clin Invest 81(5): 1572-1577. doi:10.1172/jci113490

6. Nelson JB, Hedican SP, George DJ, Reddi AH, Piantadosi S, Eisenberger MA, Simons JW (1995) Identification of endothelin1 in the pathophysiology of metastatic adenocarcinoma of the prostate. Nat Med 1(9):944-949

7. Yi B, Williams PJ, Niewolna M, Wang Y, Yoneda T (2002) Tumorderived platelet-derived growth factor-BB plays a critical role in osteosclerotic bone metastasis in an animal model of human breast cancer. Cancer Res 62(3):917-923

8. Kirschenbaum A, Liu XH, Yao S, Leiter A, Levine AC (2011) Prostatic acid phosphatase is expressed in human prostate cancer bone metastases and promotes osteoblast differentiation. Ann N Y Acad Sci 1237:64-70. doi:10.1111/j.1749-6632.2011.06198.x

9. Larson SR, Chin J, Zhang X, Brown LG, Coleman IM, Lakely B, Tenniswood M, Corey E, Nelson PS, Vessella RL, Morrissey C (2014) Prostate cancer derived prostatic acid phosphatase promotes an osteoblastic response in the bone microenvironment. Clin Exp Metastasis 31(2):247-256. doi:10.1007/s10585-013-9625-2

10. Schwartz GG (2008) Prostate cancer, serum parathyroid hormone, and the progression of skeletal metastases. Cancer Epidemiol Biomark Prev 17(3):478-483. doi:10.1158/1055-9965.EPI-072747

11. Guise TA, Yin JJ, Taylor SD, Kumagai Y, Dallas M, Boyce BF, Yoneda T, Mundy GR (1996) Evidence for a causal role of parathyroid hormone-related protein in the pathogenesis of human breast cancer-mediated osteolysis. J Clin Invest 98(7):1544-1549. doi:10.1172/jci118947

12. Shimo T, Kubota S, Yoshioka N, Ibaragi S, Isowa S, Eguchi T, Sasaki A, Takigawa M (2006) Pathogenic role of connective tissue growth factor (CTGF/CCN2) in osteolytic metastasis of breast cancer. Journal of bone and mineral research : the official journal of the American Society for Bone and Mineral Research 21(7):10451059. doi:10.1359/jbmr.060416

13. Powell GJ, Southby J, Danks JA, Stillwell RG, Hayman JA, Henderson MA, Bennett RC, Martin TJ (1991) Localization of parathyroid hormone-related protein in breast cancer metastases: increased incidence in bone compared with other sites. Cancer Res 51(11):3059-3061

14. Kakonen SM, Selander KS, Chirgwin JM, Yin JJ, Burns S, Rankin WA, Grubbs BG, Dallas M, Cui Y, Guise TA (2002) Transforming growth factor-beta stimulates parathyroid hormone-related protein and osteolytic metastases via Smad and mitogen-activated protein kinase signaling pathways. J Biol Chem 277(27):24571-24578. doi:10.1074/jbc.M202561200

15. Virk MS, Lieberman JR (2007) Tumor metastasis to bone. Arthritis Res Ther 9(Suppl 1):S5. doi:10.1186/ar2169

16. Boyle WJ, Simonet WS, Lacey DL (2003) Osteoclast differentiation and activation. Nature 423(6937):337-342. doi:10.1038/nature01658

17. Dougall WC (2012) Molecular pathways: osteoclast-dependent and osteoclast-independent roles of the RANKL/RANK/OPG pathway in tumorigenesis and metastasis. Clin Cancer Res 18(2):326-335. doi:10.1158/1078-0432.CCR-10-2507

18. Lacey DL, Tan HL, Lu J, Kaufman S, Van G, Qiu W, Rattan A, Scully S, Fletcher F, Juan T, Kelley M, Burgess TL, Boyle WJ, Polverino AJ (2000) Osteoprotegerin ligand modulates murine osteoclast survival in vitro and in vivo. Am J Pathol 157(2):435-448. doi:10.1016/s0002-9440(10)64556-7

19. Nakagawa N, Kinosaki M, Yamaguchi K, Shima N, Yasuda H, Yano K, Morinaga T, Higashio K (1998) RANK is the essential signaling receptor for osteoclast differentiation factor in osteoclastogenesis. Biochem Biophys Res Commun 253(2):395-400. doi:10.1006/bbrc.1998.9788

20. Chirgwin JM, Guise TA (2000) Molecular mechanisms of tumorbone interactions in osteolytic metastases. Crit Rev Eukaryot Gene Expr 10(2):159-178

21. Roodman DG (2007) Pathogenesis of lung cancer bone metastasis: E06-01. J Thorac Oncol 2(8):S231. doi:10.1097/01. JTO.0000283007.16865.fd

22. Roodman GD (2010) Pathogenesis of myeloma bone disease. J Cell Biochem 109(2):283-291. doi:10.1002/jcb.22403

23. Kozlow W, Guise TA (2005) Breast cancer metastasis to bone: mechanisms of osteolysis and implications for therapy. J Mammary Gland Biol Neoplasia 10(2):169-180. doi:10.1007/s10911-005-5399-8

24. Yucel B, Celasun MG, Oztoprak B, Hasbek Z, Bahar S, Kacan T, Bahceci A, Seker MM (2015) The negative prognostic impact of bone metastasis with a tumor mass. Clinics (Sao Paulo, Brazil) 70(8):535-540. doi:10.6061/clinics/2015(08)01

25. Morrissey C, Roudier MP, Dowell A, True LD, Ketchanji M, Welty C, Corey E, Lange PH, Higano CS, Vessella RL (2013) Effects of androgen deprivation therapy and bisphosphonate treatment on bone in patients with metastatic castration-resistant prostate cancer: results from the University of Washington Rapid Autopsy Series. Journal of bone and mineral research : the official journal of the American Society for Bone and Mineral Research 28(2):333-340. doi:10.1002/jbmr.1749

26. Yates AJ, Gutierrez GE, Smolens P, Travis PS, Katz MS, Aufdemorte TB, Boyce BF, Hymer TK, Poser JW, Mundy GR (1988) Effects of a synthetic peptide of a parathyroid hormonerelated protein on calcium homeostasis, renal tubular calcium 
reabsorption, and bone metabolism in vivo and in vitro in rodents. $\mathrm{J}$ Clin Invest 81(3):932-938. doi:10.1172/jci113406

27. Murray RM, Grill V, Crinis N, Ho PW, Davison J, Pitt P (2001) Hypocalcemic and normocalcemic hyperparathyroidism in patients with advanced prostatic cancer. J Clin Endocrinol Metab 86(9): 4133-4138. doi:10.1210/jcem.86.9.7864

28. Tucci M, Mosca A, Lamanna G, Porpiglia F, Terzolo M, Vana F, Cracco C, Russo L, Gorzegno G, Tampellini M, Torta M, Reimondo G, Poggio M, Scarpa RM, Angeli A, Dogliotti L, Berruti A (2009) Prognostic significance of disordered calcium metabolism in hormone-refractory prostate cancer patients with metastatic bone disease. Prostate Cancer Prostatic Dis 12(1):94-99. doi:10.1038/pcan.2008.10

29. Body JJ, Bone HG, de Boer RH, Stopeck A, Van Poznak C, Damiao R, Fizazi K, Henry DH, Ibrahim T, Lipton A, Saad F, Shore N, Takano T, Shaywitz AJ, Wang H, Bracco OL, Braun A, Kostenuik PJ (2015) Hypocalcaemia in patients with metastatic bone disease treated with denosumab. European journal of cancer (Oxford, England : 1990) 51(13):1812-1821. doi:10.1016/j.ejca.2015.05.016

30. Lumachi F, Brunello A, Roma A, Basso U (2009) Cancer-induced hypercalcemia. Anticancer Res 29(5):1551-1555

31. Basso U, Maruzzo M, Roma A, Camozzi V, Luisetto G, Lumachi F (2011) Malignant hypercalcemia. Curr Med Chem 18(23):3462-3467

32. Body JJ (2004) Hypercalcemia of malignancy. Semin Nephrol 24(1):48-54

33. Jick S, Li L, Gastanaga VM, Liede A (2015) Prevalence of hypercalcemia of malignancy among cancer patients in the UK: analysis of the clinical practice research datalink database. Cancer Epidemiol 39(6):901-907. doi:10.1016/j.canep.2015.10.012

34. Gastanaga VM, Schwartzberg LS, Jain RK, Pirolli M, Quach D, Quigley JM, Mu G, Scott Stryker W, Liede A (2016) Prevalence of hypercalcemia among cancer patients in the United States. Cancer Med 5(8):2091-2100. doi:10.1002/cam4.749

35. Soyfoo MS, Brenner K, Paesmans M, Body JJ (2013) Nonmalignant causes of hypercalcemia in cancer patients: a frequent and neglected occurrence. Supportive care in cancer : official journal of the Multinational Association of Supportive Care in Cancer 21(5):1415-1419. doi:10.1007/s00520-012-1683-5

36. Major P (2002) The use of zoledronic acid, a novel, highly potent bisphosphonate, for the treatment of hypercalcemia of malignancy. Oncologist 7(6):481-491

37. Stewart AF (2005) Clinical practice. Hypercalcemia associated with cancer. N Engl J Med 352(4):373-379. doi:10.1056/NEJMcp042806

38. Burtis WJ, Brady TG, Orloff JJ, Ersbak JB, Warrell RP Jr, Olson BR, TL W, Mitnick ME, Broadus AE, Stewart AF (1990) Immunochemical characterization of circulating parathyroid hormone-related protein in patients with humoral hypercalcemia of cancer. N Engl J Med 322(16): 1106-1112. doi:10.1056/nejm199004193221603

39. Grill V, Ho P, Body JJ, Johanson N, Lee SC, Kukreja SC, Moseley JM, Martin TJ (1991) Parathyroid hormone-related protein: elevated levels in both humoral hypercalcemia of malignancy and hypercalcemia complicating metastatic breast cancer. J Clin Endocrinol Metab 73(6):1309-1315. doi:10.1210/jcem-73-6-1309

40. Ralston SH, Fogelman I, Gardiner MD, Boyle IT (1984) Relative contribution of humoral and metastatic factors to the pathogenesis of hypercalcaemia in malignancy. Br Med J (Clin Res Ed) 288(6428):1405-1408

41. Donovan PJ, Achong N, Griffin K, Galligan J, Pretorius CJ, McLeod DS (2015) PTHrP-mediated hypercalcemia: causes and survival in 138 patients. J Clin Endocrinol Metab 100(5):2024 2029. doi: $10.1210 /$ jc. $2014-4250$

42. Galindo RJ, Romao I, Valsamis A, Weinerman S, Harris YT (2016) Hypercalcemia of malignancy and colorectal cancer. World J Oncol 7(1):5-12. doi:10.14740/wjon953w

43. Li X, Bie Z, Zhang Z, Li Y, Hu X, Liu W, Zhang S, Cheng G, Ai B (2015) Clinical analysis of 64 patients with lung-cancer-associated hypercalcemia. J Cancer Res Ther 11(Suppl):C275-C279. doi:10.4103/0973-1482.170539

44. de Wit S, Cleton FJ (1994) Hypercalcemia in patients with breast cancer: a survival study. J Cancer Res Clin Oncol 120(10):610-614

45. Truong NU, deB Edwardes MD, Papavasiliou V, Goltzman D, Kremer R (2003) Parathyroid hormone-related peptide and survival of patients with cancer and hypercalcemia. Am J Med 115(2):115121

46. Mirrakhimov AE (2015) Hypercalcemia of malignancy: an update on pathogenesis and management. N Am J Med Sci 7(11):483-493. doi:10.4103/1947-2714.170600

47. Hosking DJ, Cowley A, Bucknall CA (1981) Rehydration in the treatment of severe hypercalcaemia. The Quarterly journal of medicine 50(200):473-481

48. Rogers MJ, Gordon S, Benford HL, Coxon FP, Luckman SP, Monkkonen J, Frith JC (2000) Cellular and molecular mechanisms of action of bisphosphonates. Cancer 88(12 Suppl):2961-2978

49. Body JJ, Mancini I (2003) Treatment of tumor-induced hypercalcemia: a solved problem? Expert Rev Anticancer Ther 3(2):241-246. doi:10.1586/14737140.3.2.241

50. European Medicines Agency (2015) Zometa (zoledronic acid) Summary of product characteristics. http://www.ema.europa. eu/docs/en_GB/document_library/EPAR_-Product Information/human/000336/WC500051730.pdf. Accessed $1 \overline{2}$ October 12.10 .15

51. Food and Drug Administration (2015) Zometa (zoledronic acid) Prescribing information. https://www.pharma.us.novartis. com/product/pi/pdf/Zometa.pdf. Accessed 12 October 12.10.15

52. Major P, Lortholary A, Hon J, Abdi E, Mills G, Menssen HD, Yunus F, Bell R, Body J, Quebe-Fehling E, Seaman J (2001) Zoledronic acid is superior to pamidronate in the treatment of hypercalcemia of malignancy: a pooled analysis of two randomized, controlled clinical trials. Journal of clinical oncology : official journal of the American Society of Clinical Oncology 19(2):558-567

53. MI H, Glezerman IG, Leboulleux S, Insogna K, Gucalp R, Misiorowski W, Yu B, Zorsky P, Tosi D, Bessudo A, Jaccard A, Tonini G, Ying W, Braun A, Jain RK (2014) Denosumab for treatment of hypercalcemia of malignancy. J Clin Endocrinol Metab 99(9):3144-3152. doi:10.1210/jc.2014-1001

54. Henrich D, Hoffmann M, Uppenkamp M, Bergner R (2006) Ibandronate for the treatment of hypercalcemia or nephrocalcinosis in patients with multiple myeloma and acute renal failure: case reports. Acta Haematol 116(3):165-172. doi:10.1159/000094676

55. Body JJ, Diel IJ, Tripathy D, Bergstrom B (2006) Intravenous ibandronate does not affect time to renal function deterioration in patients with skeletal metastases from breast cancer: phase III trial results. Eur J Cancer Care (Engl) 15(3):299-302. doi:10.1111/j.1365-2354.2005.00641.x

56. Body JJ, Louviaux I, Dumon JC (2000) Decreased efficacy of bisphosphonates for recurrences of tumor-induced hypercalcemia. Supportive care in cancer : official journal of the Multinational Association of Supportive Care in Cancer 8(5):398-404

57. Kostenuik PJ, Nguyen HQ, McCabe J, Warmington KS, Kurahara C, Sun N, Chen C, Li L, Cattley RC, Van G, Scully S, Elliott R, Grisanti M, Morony S, Tan HL, Asuncion F, Li X, Ominsky MS, Stolina M, Dwyer D, Dougall WC, Hawkins N, Boyle WJ, Simonet WS, Sullivan JK (2009) Denosumab, a fully human monoclonal antibody to RANKL, inhibits bone resorption and increases BMD in knock-in mice that express chimeric (murine/human) RANKL. Journal of bone and mineral research : the official journal of the American Society for Bone and Mineral Research 24(2):182-195. doi:10.1359/jbmr.081112

58. Food and Drug Administration (2015) XGEVA (denosumab) Prescribing information. http://www.accessdata.fda. gov/drugsatfda docs/label/2013/125320s094lbl.pdf. Accessed 12 October $12.10 . \overline{15}$ 
59. Therapeutic Goods Administration Australia (2016) XGEVA (denosumab) Product information. https://www.ebs.tga.gov. au/ebs/picmi/picmirepository.nsf/pdf?OpenAgent\&id = CP-2012PI-02073-3\&d = 2016050316114622483. Accessed 03 May 03.05.16

60. Health Canada (2015) XGEVA (denosumab) Product monograph. https://www.amgen.ca/Xgeva_PM.pdf. Accessed 03 May 03.05.16

61. Russian State register of medicines (2015) Registration certificate. http://grls.rosminzdrav.ru/Grls_View_v2.aspx?idReg $=425821 \& \mathrm{t}$. Accessed 28 June 28.06.16

62. von Moos R, Body JJ, Egerdie B, Stopeck A, Brown J, Fallowfield L, Patrick DL, Cleeland C, Damyanov D, Palazzo FS, Marx G, Zhou Y, Braun A, Balakumaran A, Qian Y (2016) Pain and analgesic use associated with skeletal-related events in patients with advanced cancer and bone metastases. Supportive care in cancer : official journal of the Multinational Association of Supportive Care in Cancer 24(3):1327-1337. doi:10.1007/s00520-015-2908-1

63. European Medicines Agency (2015) XGEVA (denosumab) Summary of product characteristics. http://www.ema.europa. eu/docs/en_GB/document_library/EPAR_-_Product Information/human/002173/WC500110381.pdf. Accessed $1 \overline{2}$ October 12.10 .15

64. Lipton A, Theriault RL, Hortobagyi GN, Simeone J, Knight RD, Mellars K, Reitsma DJ, Heffernan M, Seaman JJ (2000) Pamidronate prevents skeletal complications and is effective palliative treatment in women with breast carcinoma and osteolytic bone metastases: long term follow-up of two randomized, placebocontrolled trials. Cancer 88(5):1082-1090

65. Rosen LS, Gordon D, Tchekmedyian NS, Yanagihara R, Hirsh V, Krzakowski M, Pawlicki M, De Souza P, Zheng M, Urbanowitz G, Reitsma D, Seaman J (2004) Long-term efficacy and safety of zoledronic acid in the treatment of skeletal metastases in patients with non-small cell lung carcinoma and other solid tumors: a randomized, phase III, double-blind, placebo-controlled trial. Cancer 100(12):2613-2621. doi:10.1002/cncr.20308

66. Saad F, Gleason DM, Murray R, Tchekmedyian S, Venner P, Lacombe L, Chin JL, Vinholes JJ, Goas JA, Zheng M (2004) Long-term efficacy of zoledronic acid for the prevention of skeletal complications in patients with metastatic hormone-refractory prostate cancer. J Natl Cancer Inst 96(11):879-882

67. Saad F, McKiernan J, Eastham J (2006) Rationale for zoledronic acid therapy in men with hormone-sensitive prostate cancer with or without bone metastasis. Urol Oncol 24(1):4-12. doi:10.1016/j. urolonc.2005.06.020

68. Fizazi K, Carducci M, Smith M, Damiao R, Brown J, Karsh L, Milecki P, Shore N, Rader M, Wang H, Jiang Q, Tadros S, Dansey R, Goessl C (2011) Denosumab versus zoledronic acid for treatment of bone metastases in men with castration-resistant prostate cancer: a randomised, double-blind study. Lancet (London, England) 377(9768):813-822. doi:10.1016/s0140-6736 (10)62344-6

69. Diel IJ, Body JJ, Stopeck AT, Vadhan-Raj S, Spencer A, Steger G, von Moos R, Goldwasser F, Feng A, Braun A (2015) The role of denosumab in the prevention of hypercalcaemia of malignancy in cancer patients with metastatic bone disease. European journal of cancer (Oxford, England : 1990) 51(11):1467-1475. doi:10.1016/j. ejca.2015.04.017

70. Henry DH, Costa L, Goldwasser F, Hirsh V, Hungria V, Prausova J, Scagliotti GV, Sleeboom H, Spencer A, Vadhan-Raj S, von Moos R, Willenbacher W, Woll PJ, Wang J, Jiang Q, Jun S, Dansey R, Yeh H (2011) Randomized, double-blind study of denosumab versus zoledronic acid in the treatment of bone metastases in patients with advanced cancer (excluding breast and prostate cancer) or multiple myeloma. Journal of clinical oncology : official journal of the American Society of Clinical Oncology 29(9):1125-1132. doi:10.1200/jco.2010.31.3304
71. Stopeck AT, Lipton A, Body JJ, Steger GG, Tonkin K, de Boer RH, Lichinitser M, Fujiwara Y, Yardley DA, Viniegra M, Fan M, Jiang Q, Dansey R, Jun S, Braun A (2010) Denosumab compared with zoledronic acid for the treatment of bone metastases in patients with advanced breast cancer: a randomized, double-blind study. Journal of clinical oncology : official journal of the American Society of Clinical Oncology 28(35):5132-5139. doi:10.1200/jco.2010.29.7101

72. Vaughn CB, Vaitkevicius VK (1974) The effects of calcitonin in hypercalcemia in patients with malignancy. Cancer 34(4):1268-1271

73. Szentirmai M, Constantinou C, Rainey JM, Loewenstein JE (1995) Hypocalcemia due to avid calcium uptake by osteoblastic metastases of prostate cancer. The Western journal of medicine 163(6): 577-578

74. Domschke C, Schuetz F (2014) Side effects of bone-targeted therapies in advanced breast cancer. Breast care (Basel, Switzerland) 9(5):332-336. doi:10.1159/000368844

75. Kukreja SC, Shanmugam A, Lad TE (1988) Hypocalcemia in patients with prostate cancer. Calcif Tissue Int 43(6):340-345

76. Blackley S, Anderson K, Berg J (2015) A case of denosumabinduced hypocalcaemia in a patient with non-metastatic prostate cancer and renal impairment. The journal of the Royal College of Physicians of Edinburgh 45(2):133-135. doi:10.4997/jrcpe.2015.209

77. Breen TL, Shane E (2004) Prolonged hypocalcemia after treatment with zoledronic acid in a patient with prostate cancer and vitamin $\mathrm{D}$ deficiency. Journal of clinical oncology : official journal of the American Society of Clinical Oncology 22(8):1531-1532. doi:10.1200/jco.2004.99.013

78. Pusulari BB, Akbar RA, Butt M, ul Haq SM (2008) Hypocalcemia with bony metastases in prostate cancer. Journal of Ayub Medical College, Abbottabad : JAMC 20(1):138-139

79. Kreutle V, Blum C, Meier C, Past M, Muller B, Schutz P, Borm K (2014) Bisphosphonate induced hypocalcaemia - report of six cases and review of the literature. Swiss Med Wkly 144:w13979. doi:10.4414/smw.2014.13979

80. Epperla N, Pathak R (2015) Hypocalcemia secondary to zoledronate therapy in a patient with low vitamin D level. WMJ : official publication of the State Medical Society of Wisconsin 114(4):163-166 quiz 167

81. Ho JW (2012) Bisphosphonate stimulation of osteoblasts and osteoblastic metastasis as a mechanism of hypocalcaemia. Med Hypotheses 78(3):377-379. doi:10.1016/j.mehy.2011.12.002

82. Ho JW, Sundar S (2012) Prolonged hypocalcemia after zoledronic acid in a patient with metastatic prostate carcinoma: did zoledronic acid trigger osteoblastic activity and avid calcium uptake? Clinical genitourinary cancer 10(1):50-53. doi:10.1016/j.clgc.2011.11.004

83. Lipton A, Fizazi K, Stopeck AT, Henry DH, Brown JE, Yardley DA, Richardson GE, Siena S, Maroto P, Clemens M, Bilynskyy B, Charu V, Beuzeboc P, Rader M, Viniegra M, Saad F, Ke C, Braun A, Jun S (2012) Superiority of denosumab to zoledronic acid for prevention of skeletal-related events: a combined analysis of 3 pivotal, randomised, phase 3 trials. European journal of cancer (Oxford, England : 1990) 48(16):3082-3092. doi:10.1016/j. ejca.2012.08.002

84. Stopeck AT, Fizazi K, Body JJ, Brown JE, Carducci M, Diel I, Fujiwara Y, Martin M, Paterson A, Tonkin K, Shore N, Sieber P, Kueppers F, Karsh L, Yardley D, Wang H, Maniar T, Arellano J, Braun A (2015) Safety of long-term denosumab therapy: results from the open label extension phase of two phase 3 studies in patients with metastatic breast and prostate cancer. Supportive care in cancer : official journal of the Multinational Association of Supportive Care in Cancer 24:447-455. doi:10.1007/s00520-0152904-5

85. Singh D, Khaira NS, Sekhon JS (2004) Symptomatic hypocalcaemia after treatment with zoledronic acid in a patient with multiple myeloma. Annals of oncology : official journal of 
the European Society for Medical Oncology / ESMO 15(12):1848. doi:10.1093/annonc/mdh479

86. Skugor M (2014) Hypocalcaemia. http://www.clevelandclinicmeded. $\mathrm{com} /$ medicalpubs/diseasemanagement/endocrinology/hypocalcemia/. Accessed 09 October 09.10.15

87. Ng K, Sargent DJ, Goldberg RM, Meyerhardt JA, Green EM, Pitot HC, Hollis BW, Pollak MN, Fuchs CS (2011) Vitamin D status in patients with stage IV colorectal cancer: findings from intergroup trial N9741. Journal of clinical oncology : official journal of the American Society of Clinical Oncology 29(12):1599-1606. doi:10.1200/JCO.2010.31.7255

88. Diel IJ, Hecker D, Hesse T, Kluikel C, Nusch A, Rohrberg R, Kurbacher C, Rueckinger S, Schilling J, Schultz H (2015) XTREME: interim analysis from a German open-label, observational non-interventional study for treatment persistence with denosumab in routine use in adults with bone metastases secondary to solid tumours. Presented at the European Cancer Congress, 25-29 September 2015, Vienna, Austria

89. Blouin J, Dragomir A, Moride Y, Ste-Marie LG, Fernandes JC, Perreault S (2008) Impact of noncompliance with alendronate and risedronate on the incidence of nonvertebral osteoporotic fractures in elderly women. Br J Clin Pharmacol 66(1):117127. doi:10.1111/j.1365-2125.2008.03178.x

90. Rossini M, Bianchi G, Di Munno O, Giannini S, Minisola S, Sinigaglia L, Adami S (2006) Determinants of adherence to osteoporosis treatment in clinical practice. Osteoporos Int 17(6):914 921. doi:10.1007/s00198-006-0073-6

91. Black DM, Delmas PD, Eastell R, Reid IR, Boonen S, Cauley JA, Cosman F, Lakatos P, Leung PC, Man Z, Mautalen C, Mesenbrink P, Hu H, Caminis J, Tong K, Rosario-Jansen T, Krasnow J, Hue TF, Sellmeyer D, Eriksen EF, Cummings SR (2007) Once-yearly zoledronic acid for treatment of postmenopausal osteoporosis. N Engl J Med 356(18):1809-1822. doi:10.1056/NEJMoa067312 